\title{
Pediatric vascular trauma in Manaus, Amazon - Brazil
}

\section{Traumatismos vasculares pediátricos na cidade de Manaus, Amazonas - Brasil}

Cleinaldo de Almeida Costa, tCBC-AM; José Emerson dos Santos Souza, AsCbC-AM²; Antônio Oliveira de Araújo3; Flávio Augusto Oliva Melo, AsCBC-AM4; Isabelle Nascimento Costa, AsCBC-AM²; Paulo Henrique Klein².

\begin{abstract}
A B S T R A C T
Objective: to assess the incidence of pediatric vascular injuries in patients treated at the Emergency Room of the Eastern Children's Hospital, in Manaus. Methods: we conducted a retrospective study of pediatric patients who suffered vascular injuries treated between February 2001 to February 2012. Results: we studied 71 patients, predominantly male (78.87\%), with a mean age of 7.63 years. The predominant mechanism of injury was stab wound in 27 patients (38.03\%). The average hospital stay was 10.18 days; 16 patients required care in intensive care unit, with average stay of 8.81 days. The main injuries occurred in the extremities, the upper limb being the most affected, with lesions of the ulnar artery in 13 (15.66\%) and radial in 10 (12.04\%). The mostly applied procedure was vascular exploration 35 (32.4\%). Complications occurred in nine patients (12.68\%). Mortality was 1.4\%, in one patient with a lesion of the common iliac vein and the inferior vena cava due fall from height. Conclusion: pediatric vascular injury occurred predominantly in the extremities. The dimensions of the injured vessels made surgical correction more complex and increased complication rates, particularly amputations.
\end{abstract}

Keywords: Trauma, Vascular. Child. Adolescent.

\section{INTRODUCTION}

In Brazil, as in most developing countries, violence is the leading cause of trauma, reaping many lives in the productive phase and generating billions of reais in expenses for hospitalization, temporary or permanent incapacitation and rehabilitation ${ }^{1,2}$.

Trauma sequelae incapacitate an even greater number of people, not counting the psychological and emotional aspects, which in children can lead to a regressive behavior in the presence of stress related to the event ${ }^{1}$. In the pediatric population, in which multisystem injuries are more frequent, mainly due to the greater absorption of energy per unit area generated by the lower body mass, trauma is a major cause of death and disability ${ }^{1,3-7}$. Vascular injury is a segment with unique features and difficult to analyze, mainly due to the small number of reported cases and technical challenges involved $^{3,4,8-10}$.

The knowledge on vascular trauma evolved mainly by the accumulated military experience in the first and second world wars, the Korean War and Vietnam one. It is right to say that among the different age groups affected by vascular lesions, the adult population was the most benefitted from this accumulated knowledge, ie, vascular lesions in adult patients have been well documented ${ }^{11-14}$. Contemporary conflicts, such as in Iraq and Afghanistan, have contributed to increase the knowledge of vascular trauma in children also ${ }^{15}$.

Severe vascular lesions occur with relatively low incidence in the pediatric population, but are associated with significant mortality and severe complications. They can be caused by penetrating wounds, closed ones or iatrogenic trauma. Vascular injury in this age group have been described in five major series totaling 204 cases, with an average of 3.3 cases per year 5,13,14,16,17.

In adults, vascular lesions are adequately treated by surgeons, with their diagnosis and surgical indication well established. However, in children, the small caliber of the blood vessels, intense vasospasm and the inability of some very young patients reporting symptoms to the medical staff, in addition to factors related to the

1 - Faculty of Medicine of Federal University of Amazonas (UFAM), Manaus, Amazonas State, Brazil. 2 - Faculty of Medicine of Amazonas State University (UEA), Manaus, Amazonas State, Brazil. 3 - Getúlio Vargas University Hospital (HUGV), Manaus, Amazonas State, Brazil. 4 - Adriano Jorge Hospital Foundation (FHAJ), Manaus, Amazonas State, Brazil. 
immaturity of their anatomical structures and their physiological responses $1,2,8,9,18-20$, compromise surgical repair or can lead to a false sense of absence of vascular injury, making this type of injury peculiar $3,9,21,22$.

This study evaluated pediatric vascular injuries in patients treated at the Emergency Room of the Eastern Children's Hospital (HPSC Zona Leste), in Manaus, a reference unit for this type of trauma.

\section{METHODS}

This is a non-randomized, retrospective study, whose data were obtained by collecting data from pediatric patients medical records, children and adolescents (zero to 14), in whom vascular injuries were identified in any body region, seen in the period from February 2001 to February 2012.

We developed a form to collect data from medical records of patients in the study. We conducted the analysis of the information contained in the medical records of these patients, followed by descriptive analysis of epidemiological information, with age, gender, type of injury, injury time, etiology, treatment period, type of surgery and evolution and possible complications.

This study was approved by the Ethics in Research Committee of the Adriano Jorge Hospital Foundation (FHAJ) in Manaus, under number 022/11.

\section{RESULTS}

Of the 71 pediatric patients who suffered vascular trauma, the majority $(78.87 \%)$ were male. The mean age was 7.63 years, ranging from one month to 14 years. The most frequent age group falls within the group of children of school age, ie over six years of age, with 42 cases (59.15\%). Stab wounds accounted for 38.03\% of the vascular lesions. The upper limb was the most affected body segment (53.52\%) in this series (Table 1 ).

In total, there were 36 different injured blood vessels, with a predominance of venous lesions (52.77\%) in relation to arterial ones (47.23\%). Vascular lesions occurred mainly in the ulnar (15.66\%), radial (12.04\%) and
Table 1. Distribution of patients as to gender. age group. trauma mechanism and topography of the lesions.

\begin{tabular}{lcr}
\hline & $\mathbf{n}$ & $\mathbf{\%}$ \\
\hline Gender & 56 & 78.87 \\
Male & 15 & 21.13 \\
Female & & \\
Age Group & 29 & 40.85 \\
0-6 years & 42 & 59.15 \\
Over 6 years & & \\
Trauma mechanism & 27 & 38.03 \\
SW & 12 & 16.9 \\
Fall from height & & \\
Topography of the lesions & 9 & 12.67 \\
Abdomen & 9 & 25.35 \\
LL $^{+}$ & 18 & 53.52 \\
UL & 38 & 5.63 \\
Neck & 4 & 2.81 \\
Chest & 2 & \\
\hline
\end{tabular}

*SW: stab wound; + UL: upper limbs; \# LL: lower limbs.

brachial (12.04\%) arteries of the total of 83 recorded vascular lesions (Table 2).

Regarding the diagnosis method, clinical examination was used in 71 patients for identification of vascular injury. In 13 cases (18.3\%), clinical examination was associated with another diagnostic method, such as arteriography (Figure 1) and ultrasound to confirm the vascular trauma. The main clinical presentation verified at the time of admission was bleeding at the site of injury (56.33\%), followed by hypovolemic shock (7.04\%).

The most common surgical procedure was vascular exploration (Figure 2 ) in $32.4 \%$ of cases, followed by vessel ligation (23.14\%) and end-to-end anastomosis (16.66\%). Postoperatively, there were complications in nine patients (12.68\%); of these, in five (55.55\%) amputation of the affected limb was necessary due to the vascular lesion (Table 3).

The average length of stay of patients was 10.18 days, ranging from one day to 55 , with the longer time related to one patient victim of trampling and presenting lesions in the femoral and external iliac arteries. In 16 cases (22.53\%), admission to the intensive care unit (ICU) was required, with an average length of stay of 8.81 days. There was one death (1.4\%) among the 71 patients attended. 
Table 2. Distribution of vascular lesions according to the type of vessel.

\begin{tabular}{lcr}
\hline & $\mathbf{n}$ & $\%$ \\
\hline Blood Vessels & & \\
Artery & 17 & 47.23 \\
Vein & 19 & 52.77 \\
Total & 36 & 100 \\
Main Blood Vessels Injured & & \\
Ulnar Artery & 13 & 15.66 \\
Radial Artery & 10 & 12.04 \\
Brachial Artery & 10 & 12.04 \\
Tibial Artery & 7 & 8.43 \\
\hline
\end{tabular}

\section{DISCUSSION}

Pediatric vascular injuries have complex management problems mainly due to the limited experience with vascular injuries in this age group, controversy surrounding conservative treatment, particular anatomy and physiology, requiring meticulous surgical technique and specialized pediatric follow-up after surgical treatment $6,14,16,17$.

The different topographies of vascular lesions generate different characteristics to trauma. Central vascular trauma is uncommon and is associated with high mortality. Vascular neck injuries usually result from penetrating trauma and are related to favorable survival rates. At the extremities, vascular trauma is associated with vasospasm, complicating both diagnosis and treatment. There is in these cases an immediate concern for the viability of the body extremity affected by the vascular trauma, since it is necessary to occur restoration of blood flow and adequate circulation for the future musculoskeletal development of the affected limb, differing from the elderly in whom collateral circulation is already present $3,8,9,10,21,23$.

Children whose age is equal to or less than five years old suffer from vascular trauma related to iatrogenic injuries $2,8,9,19-21,24,25$. Many of these injuries could be avoided by correct use of invasive techniques, such as insertion catheters for venous access ${ }^{20,25,26}$. In children older than five years of age, vascular lesions present an etiology similar to that observed in the adult population, that is,
Table 3. Distribution of patients according to surgical procedure and postoperative complications.

\begin{tabular}{lcr}
\hline & $\mathbf{n}$ & $\mathbf{\%}$ \\
\hline Surgical Procedure & & \\
Vascular exploration & 35 & 32.4 \\
Ligation of blood vessel & 25 & 23.14 \\
Termino-terminal anastomosis & 18 & 16.66 \\
Complications & & \\
Amputation & 5 & 55.55 \\
Infection & 1 & 11.11 \\
Sepsis & 2 & 22.22 \\
Death & 1 & 11.11 \\
Total & 9 & 100 \\
\hline
\end{tabular}

related to injury by firearm or stabbing wounds, falls from height, fractures, dislocations and closed trauma ${ }^{2,3,9,27}$.

When treating a vascular lesion, the surgeon should know the pathophysiology and the main signs and symptoms of this type of injury. Diagnosis can be accomplished simply by careful physical examination. When the vascular injury is in the extremities, one must check the

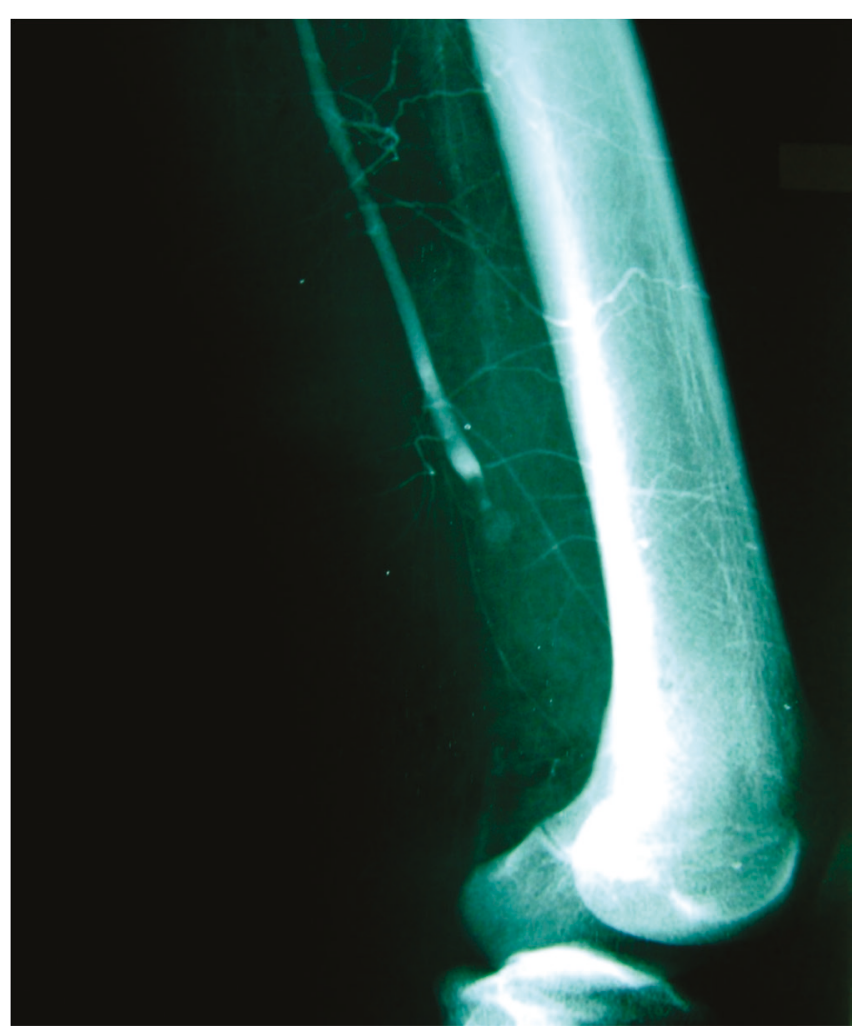

Figure 1: Contrast radiograph of pediatric patient victim of gunshot wound in lower limb showing vascular lesion. Source: author's Files. 


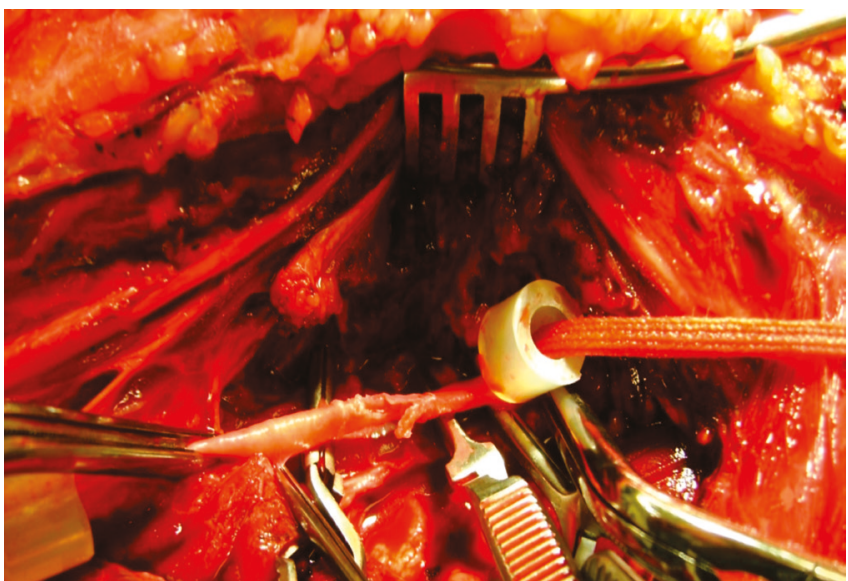

Figure 2: Femoral artery injury in pediatric patient victim of gunshot wound. Source: author's Files.

area adjacent to the lesion looking for blood infiltration into tissues. The pulses distal to the lesion should be palpated and compared with the contralateral limb when it is not injured. The temperature and the color of the extremity should be analyzed and, finally, one should auscultate the path of the main vessels near the wound $d^{5,6,16}$. Intra-abdominal or cervical arterial lesions may be diagnosed by ultrasound examinations and treated by early exploratory laparotomy and cervicotomy, respectively ${ }^{16}$. Even in the absence of signs and symptoms that confirm the possibility of vascular injury, physical examination should be repeated several times as it has been documented that the presence of signals such as distal pulses does not exclude the possibility of arterial injury and thus the symptoms of the vascular trauma can change ${ }^{13}$.

Vascular ultrasound through the duplex scan with color flow mapping of the arteries and veins is an important diagnostic method for suspected vascular trauma. The use of anatomic and hemodynamic information of the Duplex Scan, with the image in real time, makes this a versatile examination and of reasonable accuracy when there is suspicion of pediatric vascular trauma.

Preoperative arteriography remains the gold standard as a supplementary examination in cases of vascular injury in childhood, favoring the early diagnosis of injury or even excluding its possibility 5,13,14,16,17. It is important to know that the arterial vasospasm during angiography and artery manipulation is more common in pediatric patients than in adults.
The definitive treatment of a vascular injury depends on several factors. The most important are related to the type of vessel injury, the condition of the patient, the presence of materials and adequate facilities for the treatment and also the existence or not of hemorrhage ${ }^{13,16}$. Immediate surgery should be performed in situations such as the presence of persistent bleeding, pulsatile hematoma, open fracture, acute arterial insufficiency after reduction of a closed fracture, absence of pulses distal to the wound, in the upper and lower limbs or in the case of a significant amount of devitalized tissue ${ }^{13}$. Delaying the surgical treatment in order to improve collateral circulation and combat pathogens adjacent to the lesion ${ }^{14}$ is a little defined measure, because the proper development of collateral circulation to maintain tissue viability does not ensure normal growth of the extremity ${ }^{14,16}$.

When surgery is indicated, conventional surgery is still considered as the first option in treating these injuries, with the proximal and distal control of the lesion, vascular repair through direct arteriorrhaphy, use of "patch" or grafting 16,28. Procedures such as appropriate debridement of the injury, clot removal with preservation of collateral circulation, anastomosis or local artery

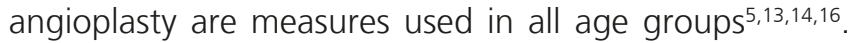
Endovascular surgery has several benefits as a treatment option for vascular trauma, such as remote approach of vascular lesions of difficult access, less invasiveness and minor intervention times. It also allows a temporary vascular control for definitive surgical repair, contributing to the stabilization of critically ill patients ${ }^{16,28}$.

Where ligation of the vessel or anastomosis cannot be made, grafts with autogenous veins, such as the saphenous, are a good option ${ }^{14,23}$. The use of synthetic prostheses in children should be the exception, as these components do not follow the vessel's longitudinal and circular growths, their diameters are generally inadequate and the permeability rate is low due to lack of endothelium $5,14,16,23$.

The advent of microsurgical techniques contributed to the treatment of low success rates vascular lesions ${ }^{16}$. In vascular repair, the use of absorbable sutures generates positive results in venous anastomosis compared to nonabsorbable ones. The use of atraumatic 
clips, such as the "Uclips" represents a major step forward, facilitating the achievement of difficult vascular anastomoses ${ }^{23}$ under optical magnification.

In cases where the vascular lesion is located in the upper or lower limbs, one should given due importance to the realization of fasciotomy. This procedure should be performed in patients with signs and symptoms of compartment syndrome or as prophylaxis for limbs affected by prolonged ischemia ${ }^{6}$.

Systemic anticoagulation with heparin sodium is an important factor in the care of acute vascular injuries, also contributing to reducing the incidence of thrombosis associated with invasive procedures such as cardiac catheterization or obtaining arterial blood gases in children ${ }^{14,23}$.

The increasing use of invasive procedures such as percutaneous arterial access or correction of congenital malformations in treatment centers for children and newborns makes the iatrogenic vascular trauma a subject for debate. Studies report that even with the increased number of invasive procedures, the rate of arterial lesions has not increased significantly. Some preventive measures should be taken to avoid iatrogenic vascular lesions, such as minimizing the number of arterial punctures in children, and the access should be limited to major arterial trunks, and perform pressure for several minutes at the site of catheter removal or puncture. When there is suspicion of arterial injury, such as fistula, thrombosis or pseudoaneurysm, one should initially perform Doppler ultrasound to verify arterial and venous patency, dilation or arteriovenous communication, and the flow rate of the vesse $\left.\right|^{23,24}$. For this type of vascular trauma, microsurgery proves advantageous, especially avoiding vascular thrombosis 10,19,20,21,24.
Outpatient regular monitoring aims to identify the decrease in pulses of affected extremities, lowering blood pressure, length differences of the limbs or clinical manifestations of arterial insufficiency, such as fatigue and lameness. These signs are indications for angiographic evaluation of the circulation of the limb affected by the vascular injury ${ }^{14}$

The complications related to vascular trauma in childhood mainly comprise abnormalities of growth and development of the limbs affected by this type of injury, stenosis in injured vessels or complications related to the severity of the trauma. However, the incidence of complications is low ${ }^{14,16}$. The neurological injury associated with the vascular one contributes to the emergence of sequelae in the affected limb $5,17,23$.

The end result after the diagnostic measures and treatment of vascular injury depends on several factors, mainly related to delays in care, experience of the surgical team to treat this type of injury, type and location of the injury and infection ${ }^{11-13}$. Early recognition and prompt treatment are considered important factors for achieving good postoperative results in pediatric patients with vascular injuries $1,2,5,6,8,10,11-14,19,29$.

The pediatric vascular trauma is a neglected public health problem. Investments in prevention, surgical staff training and acquisition of appropriate instruments are crucial to reduce morbidity and mortality.

Concluding, the pediatric vascular injury occurred predominantly in the extremities. The dimensions of the injured vessels made surgical repair more complex and increased complication rates, particularly amputations.

\title{
R E S U M O
}

\begin{abstract}
Objetivo: avaliar a incidência de traumatismos vasculares pediátricos em doentes atendidos no Hospital Pronto Socorro da Criança Zona Leste, na cidade de Manaus. Métodos: estudo retrospectivo de doentes pediátricos vítimas de traumatismos vasculares atendidos no período de fevereiro de 2001 a fevereiro de 2012. Resultados: foram estudados 71 doentes com predominância do sexo masculino $(78,87 \%)$ com média de idade de 7,63 anos. O mecanismo de trauma predominante foi o ferimento por arma branca em 27 pacientes (38,03\%). A média de internação foi 10,18 dias, com 16 doentes necessitando de cuidados em unidade de tratamento intensivo com permanência média de 8,81 dias. As principais lesões ocorreram em extremidades, com predomínio do membro superior, com lesões das artérias ulnar em 13 (15,66\%) e radial em dez (12,04\%). O procedimento mais utilizado foi a exploração vascular 35 (32,4\%). Em nove doentes (12,68\%) ocorreram complicações. A mortalidade foi 1,4\%, em um paciente com lesão da veia ilíaca comum e da veia cava inferior, devido à queda de altura. Conclusão: o traumatismo vascular pediátrico ocorreu predominantemente em extremidades. As dimensões dos vasos lesionados tornaram a correção cirúrgica mais complexa e aumentaram os índices de complicações, particularmente, de amputações.
\end{abstract}

Descritores: Traumatismo vascular. Criança. Adolescente. 


\section{REFERENCES}

1. Pereira Jr. GA, Andreghetto AC, Basile-Filho A, Andrade J. Trauma no doente pediátrico. Medicina, Ribeirão Preto. 1999;32(3):262-81.

2. Rodríguez Trejo JM, Mendoza Cortés A, Flores Padilla CM, Montuy Vidal MA, Sulvaran Aguilar A, Escotó Sánchez I. latrogenia vascular en pacientes pediátricos. Rev Mex Angiol. 2000;28(4):96-102.

3. Flanigan DP, Keifer TJ, Schuler JJ, Ryan TJ, Castronuovo JJ. Experience with iatrogenic pediatric vascular injuries. Incidence, etiology, management, and results. Ann Surg. 1983;198(4):430-42.

4. Soares G, Ibarra R, Ferral H. Abdominal aortic injury in a child: intravenous digital subtraction angiogram (IVDSA) for the diagnosis of pediatric vascular trauma. Pediatr Radiol. 2003;33(8):563-6.

5. Navarre JR, Cardillo PJ, Gorman JF, Clark PM, Martinez BD. Vascular trauma in children and adolescents. Am J Surg. 1982;143(2);229-31.

6. Myers SI, Reed MK, Black CT, Burkhalter KJ, Lowry PA. Noniatrogenic pediatric vascular trauma. J Vasc Surg. 1989;10(3):258-65.

7. American Academy of Pediatrics, pediatric Orthopaedic Society of North America. Management of pediatric trauma. Pediatrics. 2008;121(4):849-54.

8. Rodríguez-Montalbán A, Lobato-Andrés M, Acosta-Espeleta E, Gesto-Castromil R. Traumatismos vasculares en edad pediátrica. Características singulares y evolución a largo plazo. Angiología. 2007;59(2):S65-S76.

9. Mommsen P, Zeckey C, Hildebrand F, Frink M, Khaladj $\mathrm{N}$, Lange $\mathrm{N}$, et al. Traumatic extremity arterial injury in children: epidemiology, diagnostics, treatment and prognostic value of Mangled Extremity Severity Score. J Orthop Surg Res [Internet]. 2010 [acesso em 2013 fev 18];5(25):1-8. Disponível em: http://www.josr-online.com/content/5/1/25

10. Silva MAM, Burihan MC, Barros OC, Nasser F, Assis FA, Ingrund JC, et al. Trauma vascular na população pediátrica. J Vasc Bras. 2012;11(3):199-205.

11. Drapanas $T$, Hewitt RL, Weichert RF $3^{\text {rd }}$, Smith AD. Civilian vascular injuries: a critical apprais- al of three decades of management. Ann Surg. 1970;172(3):351-60.

12. Bole PV, Purdy RT, Munda RT, Moallem S, Devanesan J, Clauss RH. Civilian arterial injuries. Ann Surg. 1976;183(1):13-23.

13. Stanford JR, Evans WE, Morse TS. Pediatric arterial injuries. Angiology. 1976;27(1):1-7.

14. Whitehouse WM, Coran AG, Stanley JC, Kuhns LR, Weintraub WH, Fry WJ. Pediatric vascular trauma. Manifestations, management, and sequelae of extremity arterial injury in patients undergoing surgical treatment. Arch Surg. 1976;111(11):1269-75.

15. White JM, Stannard A, Burkhardt GE, Eastridge BJ, Blackbourne LH, Rasmussen TE. The epidemiology of vascular injury in the wars in Iraq and Afghanistan. Ann Surg. 2011;253(6):1184-9.

16. Meagher DP, Defore WW, Mattox KL, Harberg FJ. Vascular trauma in infants and children. 1979;19(7):532-6.

17. Richardson JD, Fallat M, Nagaraj HS, Groff DB, Flint LM. Arterial injuries in children. 1981;116(5):685-90.

18. Fernandes RF, Pedro LM, Evangelista A, Gimenez JL, Silvestre L, Freire JP, Fernandes JF. Tratamento endovascular de lesões arteriais traumáticas. Angiol Cir Vasc. 2011;7(1): 21-8.

19. Dzepina I, Unusic J, Mijatovic D, Bulic K. Pseudoaneurysms of the brachial artery following venipuncture in infants. Pediatr Surg Int. 2004;20(8):594-7.

20. Salvino MJ, Ramaswamy R, Schechter LS. Microvascular reconstruction of iatrogenic femoral artery thrombosis in an infant: a case report and review of the literature: infant femoral artery reconstruction. J Plast Surg. 2009;9:180-4.

21. White JJ, Talbert JL, Haller JA Jr. Peripheral arterial injuries in infants and children. Ann Surg. 1968;167(5):757-66.

22. Stewart $\mathrm{CL}$, Cohen-Kerem R, Ngan BY, Forte $\mathrm{V}$. Post-traumatic facial artery aneurysm in a child. Int J Pediatr Otorhinolaryngol. 2004;68(12):1539-43.

23. St Peter SD, Ostlie DJ. A review of vascular surgery in the pediatric population. Pediatr Surg Int. 2007;23:1-10. 
24. Lopez-Gutiérrez JC, Encinas JL, Luis A, Ros Z, Díaz M. Traumatismos arteriales en el primer año de vida. An Pediatr. 2003;59(3):290-3.

25. Allison ND, Anderson CM, Shah SK, Lally KP, Hayes-Jordan A, Tsao KJ, et al. Outcomes of truncal vascular injuries in children. J Pediatr Surg. 2009;44(10):1958-64.

26. Hsu CS, Hellinger JC, Rubin GD, Chang J. CT angiography in pediatric extremity trauma: preoperative evaluation prior to reconstructive surgery. Hand (NY). 2008;3(2):139-45.

27. Harris LM, Hordines J. Major vascular injuries in the pediatric population. Ann Vasc Surg. 2003;17(3):266-9.

28. Belczak S, Silva ES, Aun R, Sincos IR, Belon AR, Casella $\mathrm{IB}$, et al. Endovascular treatment of peripheral arterial injury with covered stents: an experimental study in pigs. Clinics (São Paulo). 2011;66(8):1425-30.

29. Rosental JJ, Gaspar MR, Gjerdrum TC, Newman J. Vascular injuries associated with fractures of the femur. Arch Surg. 1975;110(5):494-9.

Received in: 29/04/2016

Accepted for publication: 11/08/2016

Conflict of interest: none.

Source of funding: Support Fund to the Amazonas State Research - FAPEAM.

\section{Mailing address:}

Paulo Henrique Klein

E-mail: paulo_kleinn@hotmail.com 